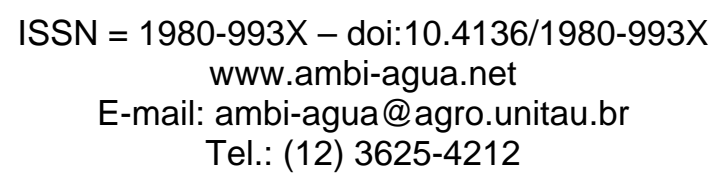

\title{
Ammonia removal from leachate by photochemical process using $\mathrm{H}_{2} \mathrm{O}_{2}$
} (doi:10.4136/ambi-agua.136)

\section{Núbia Natália de Brito ${ }^{1,2}$; José Euclides Stipp Paterniani² ${ }^{2}$ Giovani Archanjo Brota ${ }^{2}$; Ronaldo Teixeira Pelegrini ${ }^{3}$}

\author{
${ }^{1}$ Chemistry Institute. Federal University of Goiás (UFG). \\ E-mail: nubiabrito@quimica.ufg.br \\ ${ }^{2}$ College of Agricultural Engineering - Campinas State University (UNICAMP). \\ E-mail: pater@feagri.unicamp.br; giovani.brota@feagri.unicamp.br \\ ${ }^{3}$ Center for Agricultural Services CCA - Federal University of São Carlos (UFSCAR) \\ E-mail: pelegrini@cca.ufscar.br
}

\begin{abstract}
In this work, it was studied the optimization of the photochemical process using $\mathrm{H}_{2} \mathrm{O}_{2} / \mathrm{UV}$ in order to reduce the concentration of ammonia in leachate. It was used landfills leachate previously treated in the development of studies. A photochemical reactor with the capacity of 1.7 liters equipped with refrigeration system and recirculation of leachate was employed in the research. The influence of temperature, the light bulb power, the concentration of $\mathrm{H}_{2} \mathrm{O}_{2}$ and treatment time were tested during the study. A removal of $97 \%$ of ammonia was observed at $90 \mathrm{~min}$.
\end{abstract}

Keywords: landfill leachate; photochemical oxidation; solid waste.

\section{Remoção de nitrogênio amoniacal de percolado de aterro por processo fotoquímico utilizando $\mathrm{H}_{2} \mathrm{O}_{2}$}

\section{RESUMO}

Neste trabalho foi estudada a otimização do processo fotoquímico utilizando $\mathrm{H}_{2} \mathrm{O}_{2} / \mathrm{UV}$ com o propósito de reduzir a concentração de nitrogênio amoniacal. A matriz poluente em estudo foi o percolado de aterro previamente tratado. No tratamento fotoquímico utilizou-se um reator com capacidade para 1,7 litros equipado com sistema de refrigeração e recirculação do percolado. Durante o estudo foram otimizados a influência da temperatura, da potência da lâmpada, a concentração de $\mathrm{H}_{2} \mathrm{O}_{2}$ e o tempo de tratamento. Foi possível observar uma alta remoção de nitrogênio amoniacal na ordem de $97 \%$.

Palavras-chave: percolado de aterro; oxidação fotoquímica; resíduo sólido.

\section{INTRODUCTION}

The leachate is generated in landfills, resulting from the water passage through the solid waste originating from household and industrial waste in the process of decomposition (Lin and Chang, 2000). Leachate may contain high levels of organic compounds, heavy metals, ammonia, chlorine and many other soluble compounds (Cabeza et al., 2007). The physicochemical composition varies greatly depending on factors ranging from rainfall conditions, time of disposition, age of the landfill, environmental conditions and characteristics of the dump (Bertazzoli and Pelegrini, 2002; Jeong-Honn et al., 2001; Marnie et al., 2005).

Among the classes of pollutants found in leachate, ammonia has caused particular concern due to its high toxicity. Considerable concentrations of nitrogen, in ammoniacal form, can become toxic to organisms especially when present in aquatic environments. The 
BRITO, N. N.; PATERNIANI, J. E. S.; BROTA, G. A.; PELEGRINI, R. T. Ammonia removal from leachate by photochemical process using $\mathrm{H}_{2} \mathrm{O}_{2}$. Ambi-Agua, Taubaté, v. 5, n. 2, p. 51-60, 2010. (doi:10.4136/ambiagua.136)

most toxic form of ammonia is the one non-ionized $\left(\mathrm{NH}_{3}\right)$, because it interacts with the nervous system of vertebrate organisms such as fish.

Excessive nitrogen in water, in the form of nutrient, can result in eutrophication. This effect is usually characterized by the increase of aquatic plants to determined levels which may be considered the cause of interference so that, compromising the use of the water body (Kim et al., 2005).

Several biological processes of nitrification can decompose ammonia by techniques of aerobic and anaerobic treatment, however these methods have not been satisfactory (Kim et al., 2006). The photochemical technique using ultraviolet radiation and hydrogen peroxide has been portrayed in the oxidation of organic matter, and in the efficiency to reduce color in effluent, however, it has been reported that this method is inefficient to remove ammonia (Cabeza et al., 2007).

In this study, we have researched several methods of photochemical oxidation using hydrogen peroxide and UV radiation for the degradation of ammonia found in the leachate.

\subsection{Photochemical Mechanisms}

One way to employ the Homogeneous Photochemica is based on the generation of the hydroxyl radical $(\mathrm{OH})$ from hydrogen peroxide. The use of hydrogen peroxide combined with UV radiation generates the hydroxyl radical, which is a chemical agent with great power of oxidation. Radiation below $400 \mathrm{~nm}$ is capable of photolize $\mathrm{H}_{2} \mathrm{O}_{2}$ causing the split of the molecule into two hydroxyl radicals (Equation 1).

$$
\mathrm{H}_{2} \mathrm{O}_{2}+h \mathrm{v} \rightarrow 2 \mathrm{OH}^{\circ}
$$

The reaction of the hydroxyl radical is very efficient because its oxidation potential $\left(\mathrm{E}^{0}=+2.8 \mathrm{~V}\right)$ is much higher than that of the molecular hydrogen peroxide $\left(\mathrm{E}^{\circ}=+1.78 \mathrm{~V}\right)$, and it can cause a stronger oxidation. Furthermore, the hydroxyl radicals react with almost any type of substance, subtracting from it hydrogen atoms or electrons or even being added to the substrate (Dominguez et al., 2005; Xu et al., 2005).

When ferrous ions are present, the photolysis with hydrogen peroxide can be catalyzed to the hydroxyl radical formation (Photo-Fenton process). In this case, the $\mathrm{Fe}^{2+}$ ions decompose the $\mathrm{H}_{2} \mathrm{O}_{2}$ into a redox reaction that leads to the generation of hydroxyl radicals (Equation 2) (Walling, 1975).

$$
\mathrm{H}_{2} \mathrm{O}_{2}+\mathrm{Fe}^{2+} \rightarrow \mathrm{Fe}^{3+}+\mathrm{OH}+\mathrm{OH}^{-}
$$

The $\mathrm{Fe}^{3+}$ ion, formed during the process, can be regenerated to $\mathrm{Fe}^{2+}$ with the generation of more hydroxyl radical (Equation 3). This shows the catalytic character of ferrous ions, which can be regenerated in the Photo-Fenton process (Gozzo, 2001).

$\mathrm{Fe}^{3+}+\mathrm{H}_{2} \mathrm{O}+(\mathrm{UV}$ or Vis $) \rightarrow \mathrm{Fe}^{2+}+\mathrm{H}^{+}+\mathrm{OH}$

\subsection{The Chemical Oxidation of Ammonia by the Hydroxyl Radical}

Kim and collaborators (2005), studied the chemical oxidation of ammonia by the hydroxyl radical in its several complicated steps. The decomposition of ammonia can occur through direct oxidation with the hydroxyl radical so that, forming various compounds of nitrogen, among them, the nitrogen gas, nitrogen oxides $\left(\mathrm{NO}_{\mathrm{X}}\right)$ and ionic compounds such as nitrite and nitrate (Equations 4 and5).

$$
\begin{aligned}
& \mathrm{NH}_{4}^{+} \leftrightarrow \mathrm{NH}_{3}+\mathrm{OH} \rightarrow \mathrm{NH}_{2} \mathrm{OH} \rightarrow \mathrm{NOH} \rightarrow \mathrm{NO} \rightarrow \mathrm{NO}_{2}^{-} \leftrightarrow \mathrm{NO}_{3}^{-} \\
& \mathrm{NO} \rightarrow \mathrm{N}_{2} \mathrm{O} \rightarrow \mathrm{N}_{2}
\end{aligned}
$$


BRITO, N. N.; PATERNIANI, J. E. S.; BROTA, G. A.; PELEGRINI, R. T. Ammonia removal from leachate by photochemical process using $\mathrm{H}_{2} \mathrm{O}_{2}$. Ambi-Agua, Taubaté, v. 5, n. 2, p. 51-60, 2010. (doi:10.4136/ambiagua.136)

The oxidation of ammonia can also be enhanced by increasing the concentration of hypochlorous acid or hypochlorite ions in solution (Equations 6 and 7) (Kim et al., 2006; Cabeza et al., 2007).

$$
\begin{aligned}
& 2 \mathrm{NH}_{3}+3 \mathrm{HClO} \rightarrow \mathrm{N}_{2}+3 \mathrm{HCl}+3 \mathrm{H}_{2} \mathrm{O} \\
& 2 \mathrm{NH}_{3}+3 \mathrm{OCl}^{-} \rightarrow \mathrm{N}_{2}+3 \mathrm{Cl}^{-}+3 \mathrm{H}_{2} \mathrm{O}
\end{aligned}
$$

Hypochlorous acid can be generated through the reaction of chloride with the hydroxyl radical (Equations 8 and 9), and the oxidation of ammonia may happen via indirect reaction with the hydroxyl radical (Brito, 2008).

$$
\begin{aligned}
& \mathrm{Cl}^{-}+\mathrm{OH} \rightarrow \mathrm{Cl}+\mathrm{OH}^{-} \\
& \mathrm{Cl}^{-}+\mathrm{OH} \rightarrow \mathrm{HClO}
\end{aligned}
$$

\section{MATERIALS AND METHODS}

The photochemical experiments were performed in a Pyrex glass reactor with the volume capacity of $1.7 \mathrm{~L}(100 \mathrm{~mm}$ internal diameter, $145 \mathrm{~mm}$ external diameter and total height of $300 \mathrm{~mm}$ ) equipped with cooling water system in order to control temperature. The source of ultraviolet radiation was provided by a high pressure mercury light bulb (Philips HPL-N, 250 $\mathrm{W}$ and $400 \mathrm{~W}$ ) by the removal of the outer medulla and it was placed in the center of reactor. The shake of the process was continuously maintained by the recirculation of the leachate through a hydraulic pump (Invensys BAV 1115-02U, $220 \mathrm{~V} 60 \mathrm{~Hz} 34 \mathrm{~W}$ ). The oxygen supply to the photochemical process was held by bubbling air through a sintered glass at the bottom of the reactor using a compressor with a flow control valve (Sniff Compact) (Figure 1).

The leachate used in this study was collected in the city landfill located in the city of Limeira (São Paulo, Brazil). The experiments were performed with pre-treated leachate by slow land filtration. Some physicochemical characteristics of the leachate are shown in Table 1.

Table 1. Landfill leachates characterization.

\begin{tabular}{l|cc}
\hline Parameters & In nature leachate & Pretreated leachate \\
\hline Nitrogen $\mathrm{NH}_{4}^{+}\left(\mathrm{mg} \mathrm{L}^{-1}\right)$ & 446,67 & 432,01 \\
Nitrite $\mathrm{NO}_{2}^{-}\left(\mathrm{mg} \mathrm{L}^{-1}\right)$ & 0,22 & 0,15 \\
Nitrate $\mathrm{NO}_{3}^{-}\left(\mathrm{mg} \mathrm{L}^{-1}\right)$ & 2,66 & 2,30 \\
Chloride $\left(\mathrm{mg} \mathrm{L}^{-1}\right)$ & 1825 & 1770 \\
$\mathrm{Fe}\left(\mathrm{mg} \mathrm{L}^{-1}\right)$ & 54,16 & 17,87 \\
$\mathrm{pH}$ & 8,01 & 8,14 \\
\hline
\end{tabular}

Source: Brito (2008).

In this study, for verify the efficiency of the photochemical treatment of leachate the following parameters were used: ammonia nitrogen, nitrite, nitrate, $\mathrm{pH}$, residual hydrogen peroxide.

The analysis of ammoniacal nitrogen, nitrite and nitrate were performed according to the colorimetric method, according to Standard Methods for the Examination of Water and Wastewater, 20 ${ }^{\text {th }}$ Edition (APHA, 1998).

The determination of leachate $\mathrm{pH}$ values was carried out according to potentiometric method, according to Standard Methods for the Examination of Water and Wastewater, $20^{\text {th }}$ Edition (APHA, 1998). 
BRITO, N. N.; PATERNIANI, J. E. S.; BROTA, G. A.; PELEGRINI, R. T. Ammonia removal from leachate by photochemical process using $\mathrm{H}_{2} \mathrm{O}_{2}$. Ambi-Agua, Taubaté, v. 5, n. 2, p. 51-60, 2010. (doi:10.4136/ambiagua.136)

The study of residual hydrogen peroxide was a colorimetric process measured in wavelengths of $446 \mathrm{~nm}$, based on the reaction between hydrogen peroxide and vanadate ion $\left(\mathrm{VO}_{3}{ }^{-}\right)$in acidic medium (Oliveira et al., 2001).

A: Pyrex chamber for photocatalytic reaction

B: Quartz Tube to cover the UV lamp

C: Water cooling chamber

D: Sinterized glass for forming micro-air

bubbles

E: Hydraulic pump for leach ate

recirculation

F: Tap to collect samples

$\mathrm{G}$ : Container to collect foam

$\mathrm{H}$ : Outing for the leach ate recirculation

I: Entering for the leach ate

$\mathrm{J}$ : Entry for the cooling water

$\mathrm{K}$ : Outing for the cooling water

M: Air Pump $\mathrm{L}$ : Thermometer

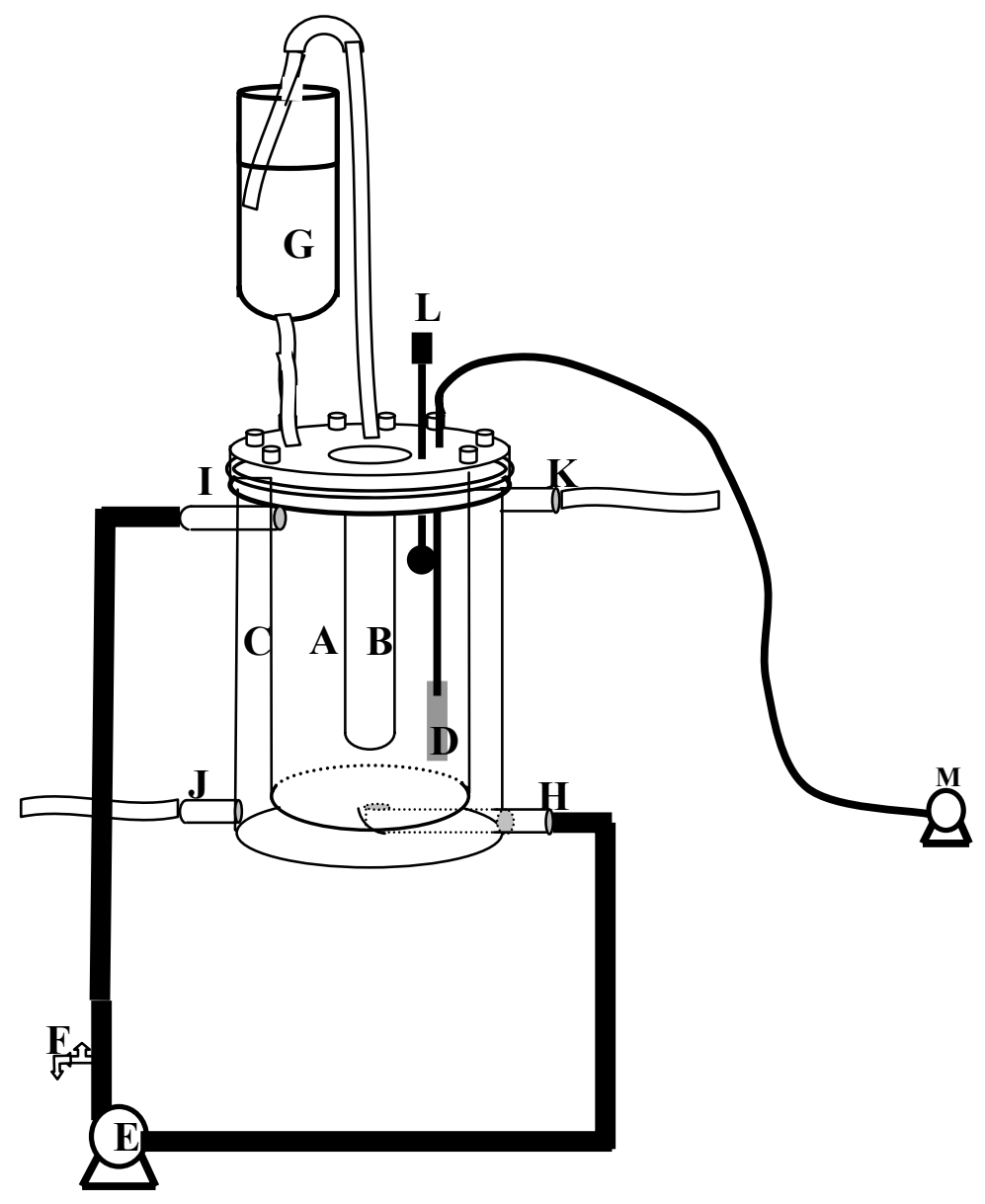

Figure 1. Schematic experimental apparatus.

\section{RESULTS AND DISCUSSION}

\subsection{The optimization of the photochemical process}

To initiate the studies of degradation of ammonia in the leachate, a $2^{3}$ factorial design (Barros Neto et al., 1995) was developed to optimize some parameters of the treatment (Table 2). In all tests performed, it was added a volume of $50 \mathrm{~mL} \mathrm{H}_{2} \mathrm{O}_{2} 10 \%\left(2.93 \mathrm{~g} \mathrm{~L}^{-1}\right)$ and it was maintained with an air flow of $15 \mathrm{~L}$ min-1. The influence of two levels in the factorial design was evaluated, one lower and one higher, for each parameter in order to reduce the ammonia concentration in leachate. It was studied: light bulb power (250 and $400 \mathrm{~W})$, temperature $\left(35\right.$ and $45^{\circ} \mathrm{C}$ ) and time of treatment (90 and $180 \mathrm{~min}$ ). After each test the concentration of the hydrogen peroxide residual was evaluated.

For a better interpretation about the effects of the combination in the parameters of reducing the concentration of ammonia, a geometric diagram was built (Figure 2), where it could be observed that the increase in temperature had a significant influence on photochemical yield showing an improvement of around $8 \%$ when the temperature increases from $35^{\circ} \mathrm{C}$ to $45^{\circ} \mathrm{C}$ in both the lower level (with $250 \mathrm{~W}$ lamp) and the upper level (with $400 \mathrm{~W}$ lamp). 
BRITO, N. N.; PATERNIANI, J. E. S.; BROTA, G. A.; PELEGRINI, R. T. Ammonia removal from leachate by photochemical process using $\mathrm{H}_{2} \mathrm{O}_{2}$. Ambi-Agua, Taubaté, v. 5, n. 2, p. 51-60, 2010. (doi:10.4136/ambiagua.136)

Table 2. $2^{3}$ Factorial Design. Optimization of the photochemical treatment for reduction of ammonia concentration in the leachate. Conditions: Volume of $\mathrm{H}_{2} \mathrm{O}_{2} 10 \% 50 \mathrm{~mL}$; air flow $15 \mathrm{~L} \mathrm{~min}^{-1}$.

\begin{tabular}{c|ccccc}
\hline Tests & Lamp & Temperature & Time & $\begin{array}{c}\text { Ammonia } \\
\text { Reduction (\%) }\end{array}$ & $\begin{array}{c}\mathbf{H}_{2} \mathbf{O}_{2} \text { residual } \\
\left(\text { mg. }^{-1}\right)\end{array}$ \\
\hline $\mathbf{1}$ & - & - & - & 54,55 & 0,143 \\
$\mathbf{2}$ & - & - & + & 65,82 & 0,057 \\
$\mathbf{3}$ & - & + & - & 62,33 & 0,094 \\
$\mathbf{4}$ & - & + & + & 78,63 & 0,026 \\
$\mathbf{5}$ & + & - & - & 75,10 & 0,045 \\
$\mathbf{6}$ & + & - & + & 78,41 & 0,003 \\
$\mathbf{7}$ & + & + & - & 84,12 & 0,028 \\
$\mathbf{8}$ & + & + & + & $\mathbf{8 6 , 4 5}$ & $\mathbf{0 , 0 0 0}$ \\
\hline
\end{tabular}

Parameters: Level (-) $250 \mathrm{~W}, 35^{0} \mathrm{C}, 90 \mathrm{~min} . /$ Level (+) $400 \mathrm{~W}, 45^{\circ} \mathrm{C}, 180 \mathrm{~min}$.

With the increase of the light bulb power to $400 \mathrm{~W}$ the efficiency of the process made an improvement from 21 to $22 \%$ at temperatures of $35^{\circ} \mathrm{C}$ and $45^{\circ} \mathrm{C}$ respectively, at the $90 \mathrm{~min}$ mark of the treatment. The same efficiency was not observed at the 180 min mark of the treatment, which remained between 8 and 12\%. Observing the terms of the lower level (temperature $35^{\circ} \mathrm{C}$, time $90 \mathrm{~min}$ and $250 \mathrm{~W}$ light bulb) and the highest level of efficiency (time 180 min temperature $45^{\circ} \mathrm{C}$ and $400 \mathrm{~W}$ lamp) the yield was above $32 \%$.

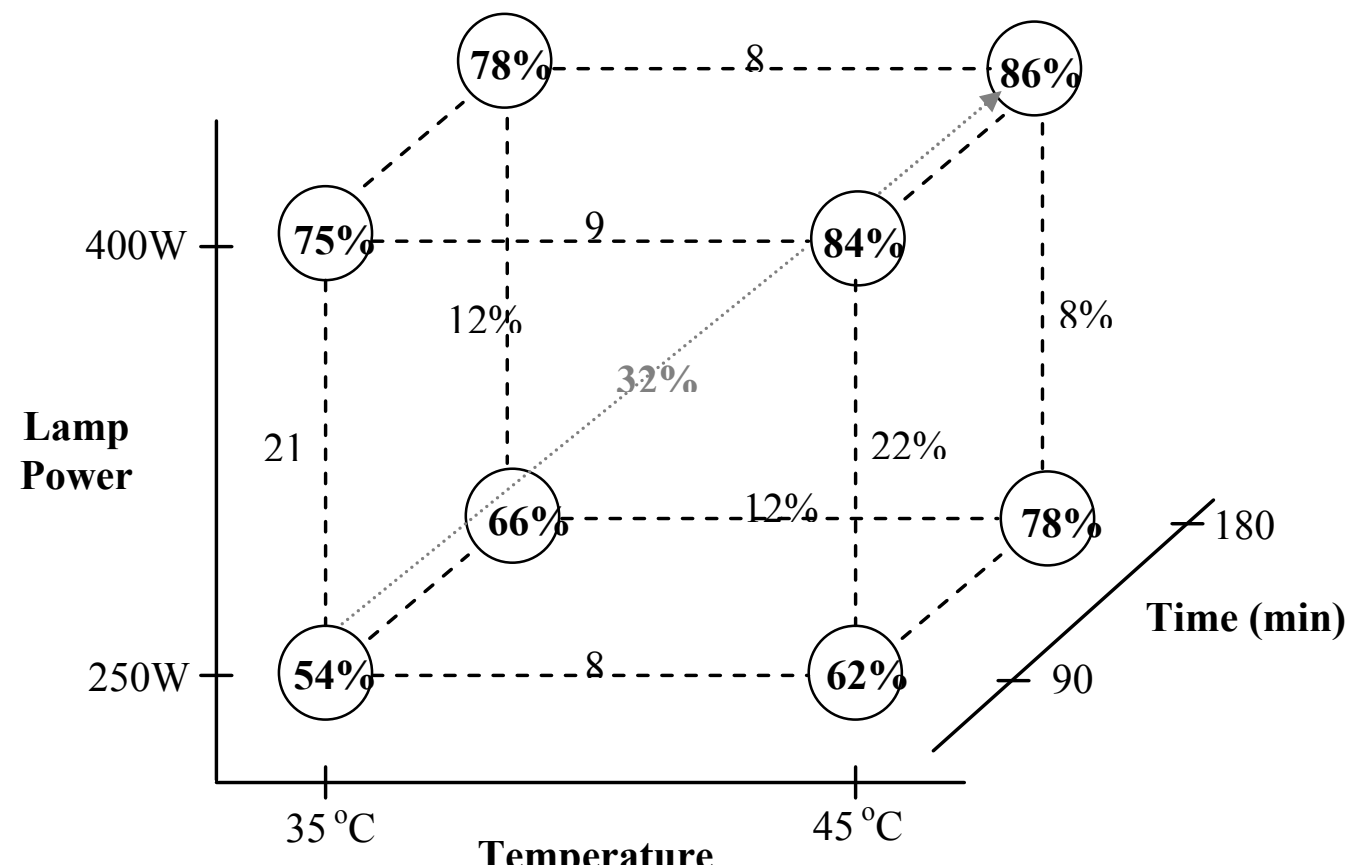

Figure 2. Diagram for geometric interpretation of the effects of lamp power, temperature and time of photochemical treatment to reduce ammonia concentration in the leachate.

By taking into account these optimized conditions, a new $3^{2}$ factorial design was developed aiming to study three concentration levels of $\mathrm{H}_{2} \mathrm{O}_{2}$ and air flow (Table 3), considering that the efficiency of the process has always been assessed by reducing the concentration of ammonia in the leachate. 
BRITO, N. N.; PATERNIANI, J. E. S.; BROTA, G. A.; PELEGRINI, R. T. Ammonia removal from leachate by photochemical process using $\mathrm{H}_{2} \mathrm{O}_{2}$. Ambi-Agua, Taubaté, v. 5, n. 2, p. 51-60, 2010. (doi:10.4136/ambiagua.136)

Table 3. $3^{2}$ Factorial Design. Optimization of photochemical treatment for reduction of ammonia concentration in the leachate. Conditions: Lamp $400 \mathrm{~W}$, temperature $45^{\circ} \mathrm{C}$, treatment time 180 $\min$.

\begin{tabular}{cccc}
\hline Tests & Volume $\mathbf{H}_{\mathbf{2}} \mathbf{O}_{\mathbf{2}}$ & Air Flow & Ammonia Reduction (\%) \\
\hline $\mathbf{1}$ & - & - & 76,53 \\
$\mathbf{2}$ & - & + & 73,47 \\
$\mathbf{3}$ & - & $\Theta$ & 75,48 \\
$\mathbf{4}$ & + & - & 89,01 \\
$\mathbf{5}$ & + & + & 86,42 \\
$\mathbf{6}$ & + & $\Theta$ & 88,14 \\
$\mathbf{7}$ & $\mathbf{\theta}$ & - & $\mathbf{9 1 , 0 8}$ \\
$\mathbf{8}$ & $\Theta$ & + & 87,36 \\
$\mathbf{9}$ & $\Theta$ & $\Theta$ & 88,64 \\
\hline
\end{tabular}

Parameters: $\quad$ Level (-) $20 \mathrm{~mL}, 1.17$ g.L. $\mathrm{L}^{-1} \mathrm{H}_{2} \mathrm{O}_{2}$ e $0,0 \mathrm{~L} \cdot \mathrm{min}^{-1}$ vazão de ar;

Level $(\Theta) 35 \mathrm{~mL}, 2.05$ g.L. $\mathrm{L}^{-1} \mathrm{H}_{2} \mathrm{O}_{2}$ e 5.0 L.min ${ }^{-1}$ vazão de ar;

Level (+) 50 mL, 2.93 g.L. $\mathrm{L}^{-1} \mathrm{H}_{2} \mathrm{O}_{2}$ e 15.0 L.min ${ }^{-1}$ vazão de ar.

For best visual results of the study, a geometric diagram was built, as shown in Figure 3. Comparing the results of photochemical treatment in each level, it was observed that when a volume of $35 \mathrm{~mL}$ with a $10 \%$ solution of $\mathrm{H}_{2} \mathrm{O}_{2}$ (concentration $2.05 \mathrm{~g} \mathrm{~L}^{-1}$ ) without the addition of air was used, the process showed a $91 \%$ reduction of ammonia concentration.

Following the work, the volumes of about $35 \mathrm{~mL}$ and addition of several aliquots at different times were studied. The four best methods are shown in Table 4.

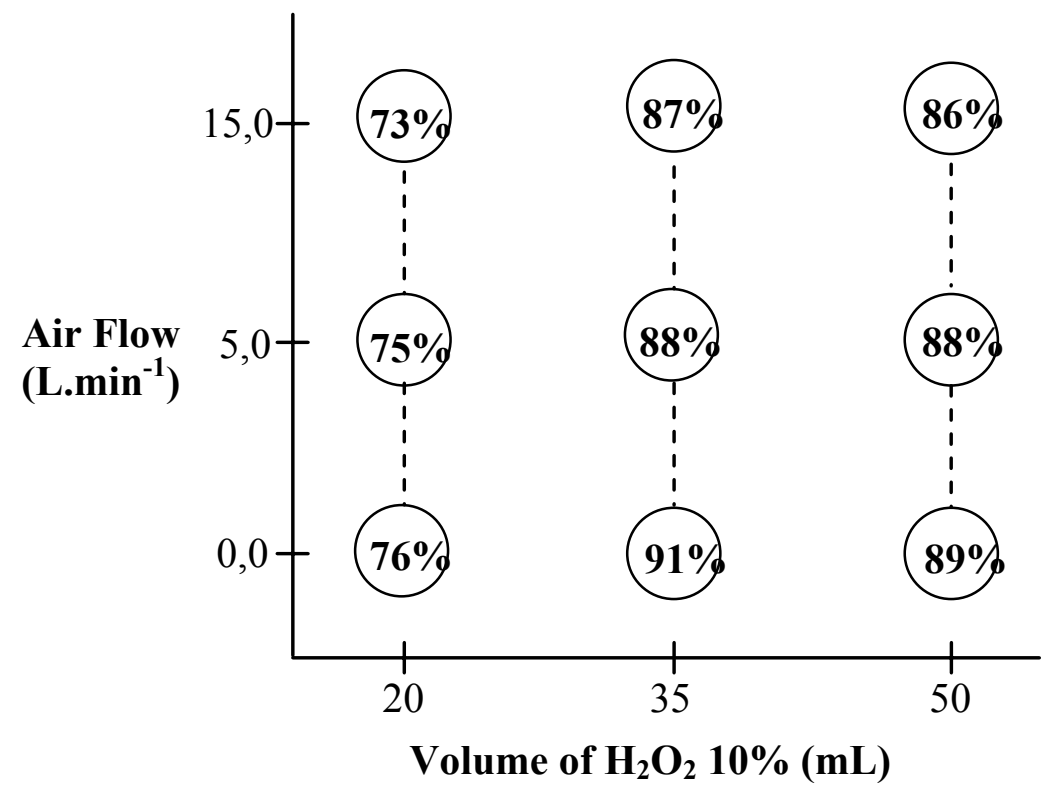

Figure 3. Diagram for the geometric interpretation on the effects of air flow and volume of $\mathrm{H}_{2} \mathrm{O}_{2} \quad 10 \%$ in the photochemical treatment to reduce ammonia concentration in the leachate. 
BRITO, N. N.; PATERNIANI, J. E. S.; BROTA, G. A.; PELEGRINI, R. T. Ammonia removal from leachate by photochemical process using $\mathrm{H}_{2} \mathrm{O}_{2}$. Ambi-Agua, Taubaté, v. 5, n. 2, p. 51-60, 2010. (doi:10.4136/ambiagua.136)

Table 4. Results of the \% reduction of ammonia concentration in leachate and sequential evaluation of residual $\mathrm{H}_{2} \mathrm{O}_{2}$. Photochemical conditions: $400 \mathrm{~W}$ light bulb, temperature $45^{\circ} \mathrm{C}$, air flow 0.00 .

\begin{tabular}{|c|c|c|c|c|}
\hline Time (min) & $\begin{array}{l}\text { (\%)st A } \\
\text { Reduction) }\end{array}$ & $\begin{array}{l}\text { Test B } \\
\text { (\% Ammonia } \\
\text { Reduction) }\end{array}$ & $\begin{array}{l}\text { Test } \mathrm{C} \\
\begin{array}{c}\text { (\% Ammonia } \\
\text { Reduction) }\end{array}\end{array}$ & 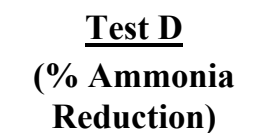 \\
\hline 0 & 0 & 0 & 0 & 0 \\
\hline 30 & 75,53 & 73,30 & 74,25 & 75,59 \\
\hline 60 & 93,26 & 92,59 & 87,35 & 86,80 \\
\hline 90 & 97,89 & $(96,91)$ & $(95,56)$ & 89,28 \\
\hline 120 & 97,92 & 97,36 & 96,00 & 90,71 \\
\hline 180 & 97,90 & 98,10 & 96,42 & 91,82 \\
\hline Methodology & $\begin{array}{c}40 \mathrm{~mL}: 20 ; 10 ; 10 \\
{\left[2,35 \text { g. } \mathrm{L}^{-1} \mathrm{H}_{2} \mathrm{O}_{2}\right]}\end{array}$ & $\begin{array}{c}35 \mathrm{~mL}: 15 ; 10 ; 10 \\
{\left[2,05 \text { g.L }{ }^{-1} \mathrm{H}_{2} \mathrm{O}_{2}\right]}\end{array}$ & $\begin{array}{l}35 \text { mL: } 20 ; 10 ; 5 \\
{\left[2,05 \text { g.L }{ }^{-1} \mathrm{H}_{2} \mathrm{O}_{2}\right]}\end{array}$ & $\begin{array}{c}30 \mathrm{~mL}: 20 ; 10 \\
{\left[1,75 \mathrm{~g} \cdot \mathrm{L}^{-1} \mathrm{H}_{2} \mathrm{O}_{2}\right]}\end{array}$ \\
\hline $\begin{array}{c}\text { Treatment } \\
\text { Time }\end{array}$ & $\begin{array}{c}\mathrm{H}_{2} \mathrm{O}_{2} \text { residual } \\
\left(\mathrm{mg}^{\left.-\mathrm{L}^{-1}\right)}\right.\end{array}$ & $\begin{array}{c}\mathrm{H}_{2} \mathrm{O}_{2} \text { residual } \\
\left(\mathrm{mg}^{-\mathrm{L}^{-1}}\right)\end{array}$ & $\begin{array}{c}\mathrm{H}_{2} \mathrm{O}_{2} \text { residual } \\
\left(\mathrm{mg}^{-\mathrm{L}^{-1}}\right)\end{array}$ & $\begin{array}{c}\mathrm{H}_{2} \mathrm{O}_{2} \text { residual } \\
\left(\mathrm{mg}^{-\mathrm{L}^{-1}}\right)\end{array}$ \\
\hline $90 \mathrm{~min}$ & 0,053 & 0,008 & 0,012 & 0,000 \\
\hline $180 \mathrm{~min}$ & 0,000 & 0,000 & 0,000 & 0,000 \\
\hline
\end{tabular}

Note: $\quad$ Methodology and volumes:

Test A (40 mL: $20 \mathrm{~mL}$ at $0 \mathrm{~min}, 10 \mathrm{~mL}$ at $30 \mathrm{~min}$ and $10 \mathrm{~mL}$ at $60 \mathrm{~min})$;

Test B (35 mL: $15 \mathrm{~mL}$ at $0 \mathrm{~min}, 10 \mathrm{~mL}$ at $30 \mathrm{~min}$ and $10 \mathrm{~mL}$ at $60 \mathrm{~min})$;

Test C (35 mL: $20 \mathrm{~mL}$ at $0 \mathrm{~min}, 10 \mathrm{~mL}$ at $30 \mathrm{~min}$ and $5 \mathrm{~mL}$ at $60 \mathrm{~min})$;

Test D (30 mL: $20 \mathrm{~mL}$ at $0 \mathrm{~min}, 10 \mathrm{~mL}$ at $30 \mathrm{~min}$ ).

For better interpretation of this study a new geometric diagram was built, prioritizing the results of reduction on ammonia concentration at times of 90 and $180 \mathrm{~min}$ (Figure 4). This figure shows that the tests $\mathrm{A}, \mathrm{B}$ and $\mathrm{C}$ presented very similar results. However, no significant differences were found in reducing the ammonia concentration when the time of treatment increased from $90 \mathrm{~min}$ to $180 \mathrm{~min}$. By observing the concentration of residual $\mathrm{H}_{2} \mathrm{O}_{2}$ at the 90 min mark, it was observed that "Test B" shows the lowest concentration $\left(0.008 \mathrm{mg} \mathrm{L}^{-1}\right)$. In this study, the methodology developed in "Test B" in time of $90 \mathrm{~min}$ was chosen, as optimized conditions for the photochemical treatment of ammonia in the leachate. Figure 5 shows a curve of the trend of ammonia degradation. Other results of environmental importance were also obtained using this method of treatment (Table 5).

Treatment

Time

(min)

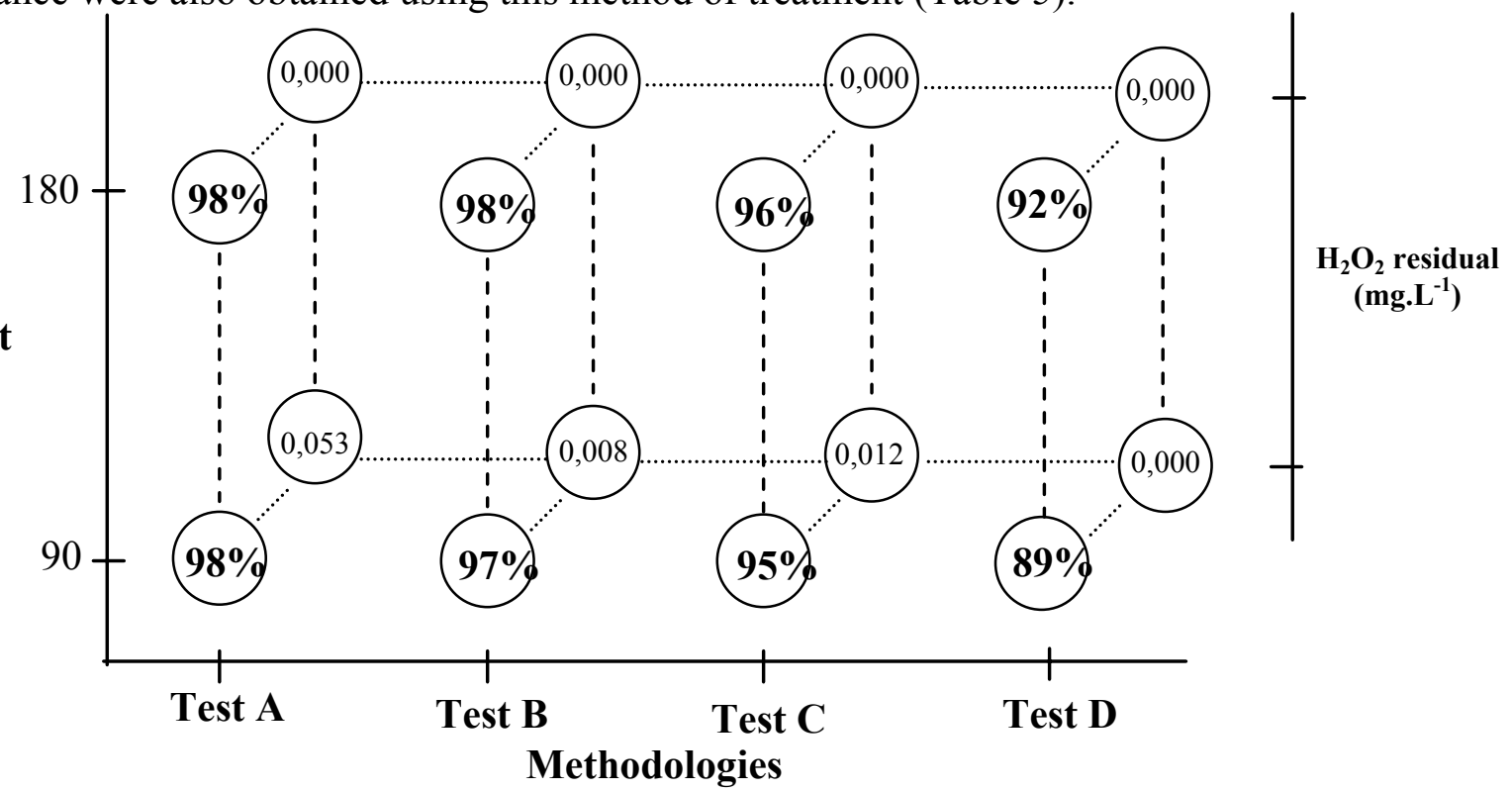

Figure 4. Diagram for the geometric interpretation of the effects of photochemical treatment time versus Methodologies of Addition to the $\mathrm{H}_{2} \mathrm{O}_{2}$ and evaluation of residual $\mathrm{H}_{2} \mathrm{O}_{2}$ to reduce the ammonia concentration in the leachate. 
BRITO, N. N.; PATERNIANI, J. E. S.; BROTA, G. A.; PELEGRINI, R. T. Ammonia removal from leachate by photochemical process using $\mathrm{H}_{2} \mathrm{O}_{2}$. Ambi-Agua, Taubaté, v. 5, n. 2, p. 51-60, 2010. (doi:10.4136/ambiagua.136)

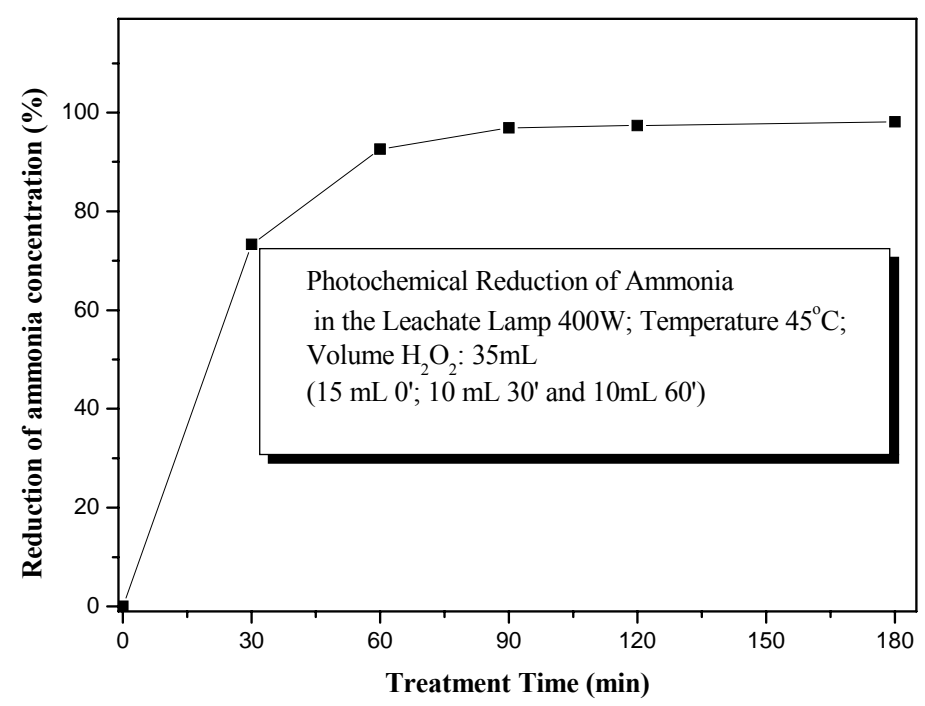

Figure 5. Evolution of the percentage of degradation of the ammonia concentration in the leachate treated by photochemical processes using $\mathrm{H}_{2} \mathrm{O}_{2}$.

Table 5. Landfill leachates characterization after the photochemical process.

\begin{tabular}{|c|c|c|c|}
\hline Parameter & $\begin{array}{c}\text { Pretreated } \\
\text { leachate }\end{array}$ & $\begin{array}{l}\text { Photochemical } \\
\text { post-treatment }\end{array}$ & $\%$ Reduction \\
\hline Nitrogen $\mathrm{NH}_{4}^{+}\left(\mathrm{mg} \mathrm{L}^{-1}\right)$ & 432,01 & 13,3 & 97,0 \\
\hline Nitrite $\mathrm{NO}_{2}^{-}\left(\mathrm{mg} \mathrm{L}^{-1}\right)$ & 0,15 & 0,05 & 66,7 \\
\hline Nitrate $\mathrm{NO}_{3}^{-}\left(\mathrm{mg} \mathrm{L}^{-1}\right)$ & 2,30 & 0,73 & 68,3 \\
\hline $\mathrm{pH}$ & 8,14 & 8,54 & - \\
\hline
\end{tabular}

\subsection{Ammonia Oxidation in Leachate}

Considering the equation 1 , it is observed the generation of hydroxyl radical from homolytic cleavage of $\mathrm{H}_{2} \mathrm{O}_{2}$ caused by $\mathrm{UV}$ radiation. The degradation of ammonia may have followed this photochemical path. However, in the leachate studied there is a concentration of $\mathrm{Fe}^{+2}$ around $18 \mathrm{mg} \mathrm{L}^{-1}$ (Table 1), leading to the production of hydroxyl radicals via mechanisms provided by equations 2 and 3, and the process would be via photo-Fenton. The leachate also presented high concentrations of chloride $\left(1770 \mathrm{mg} \mathrm{L}^{-1}\right)$ which can react with hydroxyl radical generating $\mathrm{HClO}$ and $\mathrm{ClO}^{-}$(Equations 7 and 8). These species can cause the degradation of ammonia (Equations 5 and 6).

Considering the high efficiency of the degradation of ammonia in the leachate, certainly part of the remediation was via direct mechanism of $\mathrm{H}_{2} \mathrm{O}_{2}$ cleavage through the redox reaction of $\mathrm{Fe}^{2+}$ and $\mathrm{Fe}^{3+}$ ions and also through the formation of species- $\mathrm{HClO}$ and $\mathrm{ClO}$, which would be a significant contribution in the treatment of leachate.

\section{CONCLUSIONS}

The technique of photochemical proved to be an excellent alternative in the treatment of complex wastewaters such as leachate. The optimization of the process made it possible to treat high concentrations of ammonia. It was observed that the parameters of light bulb power $(400 \mathrm{~W})$ and temperature $\left(45^{\circ} \mathrm{C}\right)$ are decisive factors in the efficiency in the photochemical process. Allied to this, the method of adding the $\mathrm{H}_{2} \mathrm{O}_{2}$ solution, at rates, favored the results of this study significantly. 
BRITO, N. N.; PATERNIANI, J. E. S.; BROTA, G. A.; PELEGRINI, R. T. Ammonia removal from leachate by photochemical process using $\mathrm{H}_{2} \mathrm{O}_{2}$. Ambi-Agua, Taubaté, v. 5, n. 2, p. 51-60, 2010. (doi:10.4136/ambiagua.136)

It was also observed through by photochemical process $\mathrm{H}_{2} \mathrm{O}_{2} / \mathrm{UV}$ and Photo Fenton process a decrease in the ammonia concentration in the order of $97 \%$, but was also observed reductions in the concentration of nitrite $(66 \%)$ and nitrate $(68 \%)$. Thus concludes that oxidation of ammonia occurs via direct oxidation (Equation 4) or can also be enhanced by increasing the concentration of hypochlorous acid or hypochlorite ions in solution with gaseous nitrogen production (Equations 5 e 6 ).

\section{ACKNOWLEDGEMENT}

This study was supported by National Council for Scientific and Technological Development (CNPq).

\section{REFERENCES}

AMERICAN PUBLIC HEALTH ASSOCIATION; AMERICAN WATHER WORKS ASSOCIATION - APHA, AWWA. Standard methods for the water and wastewater. 20. ed. New York: WPCF, 1998.

BARROS NETO, B.; SCARMINIO, I. S.; BRUNS, R. E. Planejamento e otimização de experimentos. Campinhas: Editora da Unicamp, 1995.

BERTAZZOLI, R.; PELEGRINI, R. Photoelectrochemical discoloration and degradation of organic pollutants in aqueous solutions. Química Nova, v. 25, n. 3, p. 477-482, 2002.

BRITO, N. N. Sanitary landfill leachate photocatalysis treated by slow sand filter. 2008. 30f. Dissertação (Mestrado em Engenharia Agrícola) - Faculdade de Engenharia Agrícola, Universidade Estadual de Campinas, Campinas, 2008.

CABEZA, A.; URTIAGA, M. J.; RIVERO I. O. Ammonium removal from landfill leachate by anodic oxidation. Journal Hazardous Materials, v. 144, p. 715 -719, 2007.

DOMINGUEZ, J. R.; BELTRAN, J.; RODRIGUEZ, O. Vis and UV photocatalytic detoxification methods (using $\mathrm{TiO}_{2}, \mathrm{TiO}_{2} / \mathrm{H}_{2} \mathrm{O}_{2}, \mathrm{TiO}_{2} / \mathrm{O}_{3}, \mathrm{TiO}_{2} / \mathrm{S}_{2} \mathrm{O}_{8}{ }^{2-}, \mathrm{O}_{3}, \mathrm{H}_{2} \mathrm{O}_{2}, \mathrm{~S}_{2} \mathrm{O}_{8}{ }^{2-}$, $\mathrm{Fe}^{3+} / \mathrm{H}_{2} \mathrm{O}_{2}$ and $\left.\mathrm{Fe}^{3+} / \mathrm{H}_{2} \mathrm{O}_{2} / \mathrm{C}_{2} \mathrm{O}_{4}{ }^{2-}\right)$ for dyes treatment. Catalysis Today. v. 101, n.3/4, p. 389-395, 2005.

GOZZO, F. Radical and non-radical chemistry of Fenton like systems in presence of organic substances. Journal Molecular Catalysis. A: Chemical, v. 171, p. 1-22, 2001.

JEONG-HOON, I. M.; HAE-JIN, W.; MYUNG-WON, C.; KI-BACK, H.; CHANG-WON, K. Simultaneous organic and nitrogen removal from municipal landfill leachate using an anaerobic-aerobic system. Water Research, v. 35, n. 10, p. 2043-2410, 2001.

KIM, K. W.; KIM, Y. J.; KIM, I. T.; PARK, G.; LEE, E. H. The electrolytic decomposition mechanism of ammonia to nitrogen at an $\mathrm{IrO}_{2}$ anode. Electrochemical Acta, v. 50, p. $4356-4364,2005$

KIM, K. W.; KIM, Y. J.; KIM, I. T.; PARK, G.; LEE, E. H. Electrochemical conversion characteristics of ammonia to nitrogen. Water Reseach. v. 40, p. 1431-1441, 2006.

LIN, S. H.; CHANG, C. C. Treatment of landfill leachate by combined electron-fenton oxidation and sequencing bath reactor method. Water Research, v. 34, n. 17, p. $4243-$ 4249, 2000. 
BRITO, N. N.; PATERNIANI, J. E. S.; BROTA, G. A.; PELEGRINI, R. T. Ammonia removal from leachate by photochemical process using $\mathrm{H}_{2} \mathrm{O}_{2}$. Ambi-Agua, Taubaté, v. 5, n. 2, p. 51-60, 2010. (doi:10.4136/ambiagua.136)

MARNIE, L. W.; BITTON, G.; TOWNSEN, T. Heavy metal binding capacity (HMBC) of municipal solid waste landfill leachates. Chemosphere, v. 60, n. 2, p. 206-215, 2005.

OLIVEIRA, M. C.; NOGUEIRA, R. F. P.; GOMES NETO, J. A.; JARDIM, W. F. ROHWEDDER, J. J. R. Flow injection spectrophotometric system for hydrogen peroxide monitoring in photo-fenton degradation processes. Química Nova, v. 24, n. 2, p. 188-190, 2001.

XU, T.; XIAO, M. M.; LIU, H. Y. Advanced oxidation degradation of dichlorobenzene in water by the UV/ $\mathrm{H}_{2} \mathrm{O}_{2}$ process. Journal Environment Science Health- A, v. 40, n. 4, p. 751-765, 2005.

WALLING, C. Fenton's reagent revisited. Account of Chemical Research, v. 8, p.125-131, 1975. 